\title{
Identifying Genocide: The Yazidi Massacre in the Context of the Convention on the Prevention and Punishment of Genocide 1948
}

Jade Potot-Warren, Northumbria University

In August 2014 ISIS conducted a coordinated attack on the Yazidi population of the Mount Sinjar area. As a result, the entirety of this Yazidi population was displaced ${ }^{1}$, and an estimated total of 3,100² Yazidis were killed (approximately half were executed, and the rest died whilst fleeing $^{3}$ ) and $6,800^{4}$ were kidnapped and subjected to numerous abuses, including torture and forced religious conversion. The "genocide" is ongoing ${ }^{5}$ and as of August 2014, there are an estimated 3,2006 women and girls still in ISIS captivity.

This article will explore these events in the context of the elements of genocide and with references to the findings of the Report of the Independent International Commission of Inquiry on the Syrian Arab Republic and the Report of the Office of the United Nations High Commissioner for Human Rights on the human rights situation in Iraq in the light of abuses committed by the so-called Islamic State in Iraq and the Levant and associated group. This article will critically examine if, and to what extent, these attacks constitute a genocide within the meaning of the Convention on the Prevention and Punishment of Genocide ('Genocide Convention’) 1948.

\footnotetext{
${ }^{1}$ Valeria Cetorelli, Isaac Sasson, Nazar Shabila, Gilbert Burnham'Mortality and kidnapping estimates for the Yazidi population in the area of Mount Sinjar, Iraq, in August 2014: A retrospective household survey' (2017) PLOS Medicine https://doi.org/10.1371/journal.pmed.1002297 accessed 4 May 2019

${ }^{2}$ Ibid.

${ }^{3}$ Ibid.

${ }^{4}$ Ibid.

${ }^{5}$ OHCHR, 'Report of the Independent International Commission of Inquiry on the Syrian Arab Republic' (15 June 2016) A/HRC/32/CRP.2

${ }^{6}$ Ibid.
} 


\section{Background}

The Yazidis are a longstanding ethnic and religious community, the majority of whom live in Northern $\operatorname{Iraq}^{7}$ in the Mount Sinjar area (approximately $400,000^{8}$ people), where the Islamic State of Iraq and Syria (ISIS) had been systematically targeting minority groups in the region in a brutal drive to "purify" it of non-Islamic influences?

On 3 August 2014, ISIS launched an attack specifically targeting the Yazidis and advanced convoys into the Sinjar area, surrounding the neighbouring towns and villages, and thus forcing Yazidis to seek refuge on Mount Sinjar, which ISIS subsequently encircled leaving the Yazidis trapped without supplies or shelter ${ }^{10}$. Men and older women who were unable to flee in time were executed by means of shooting or beheading ${ }^{11}$. Young women, girls and boys were kidnapped ${ }^{12}$ : the women and girls who had attained the age of $9^{13}$ were used and/or sold into sexual or domestic slavery and the young boys who had attained the age of $7^{14}$ were sent to training camps to be indoctrinated into ISIS as fighters or suicide bombers ${ }^{15}$.

\footnotetext{
${ }^{7}$ Dave van Zoonen, Khogir Wirya, 'Yazidis: Perceptions of Reconciliation and Conflict' (2017) Middle East Research Institute <www.usip.org/sites/default/files/Yazidis-Perceptions-of-Reconciliation-and-ConflictReport.pdf> accessed 4 May 2019

${ }^{8}$ Valeria Cetorelli, Isaac Sasson, Nazar Shabila, Gilbert Burnham'Mortality and kidnapping estimates for the Yazidi population in the area of Mount Sinjar, Iraq, in August 2014: A retrospective household survey’ (2017) PLOS Medicine https://doi.org/10.1371/journal.pmed.1002297 accessed 4 May 2019

${ }^{9}$ Amnesty International 'Ethnic cleansing on a historic scale: Islamic State's systematic targeting of minorities in Northern Iraq’ (2014) <www.es.amnesty.org/uploads/media/Iraq_ethnic_cleansing_final_formatted.pdf > accessed 4 May 2019

${ }^{10}$ Valeria Cetorelli, Isaac Sasson, Nazar Shabila, Gilbert Burnham‘Mortality and kidnapping estimates for the Yazidi population in the area of Mount Sinjar, Iraq, in August 2014: A retrospective household survey’ (2017) PLOS Medicine

11 ibid

12 Yazda and the Free Yezidi Foundation, 'ISIL: Nationals of ICC states parties committing genocide and other crimes against the Yazidis’ (Free Yezidi Foundation, 2015) <www.freeyezidi.org/wp-content/uploads/CorrRED-ISIL-commiting-genocide-ag-the-Yazidis.pdf> accessed 5 May 2019

${ }^{13}$ OHCHR, 'Report of the Independent International Commission of Inquiry on the Syrian Arab Republic' (15 June 2016) A/HRC/32/CRP.2

${ }^{14}$ Ibid.

15 Jewish World Watch, 'Iraq (The Yazidis)' (Jewish World Watch, 2019) <www.jww.org/conflict-areas/iraqyazidis/> accessed 4 May 2019
} 
United States humanitarian aid airdrops and helicopter rescue missions between 8 - 13 August 2014 enabled most of the trapped Yazidis to be evacuated into the Kurdistan region where the majority of the displaced population $\left(300,000^{16}\right.$ Yazidis) now reside in displaced persons camps. Others from the evacuated population are reportedly in refugee camps in Syria (around $15,000^{17}$ ), or have crossed into Turkey (at least $30,000^{18}$ ), whilst some (an estimated $10,000^{19}$ ) remain in makeshift camps on Mount Sinjar ${ }^{20}$.

\section{The Elements of Genocide}

\section{The Acts of Genocide}

Genocide can be committed in various forms ${ }^{21}$ : killing members of a group; causing serious bodily or mental harm to members of the group; deliberately inflicting on the group conditions of life calculated to bring about its physical destruction in whole or in part; imposing measures intended to prevent births within the group; or forcibly transferring children of the group to another group.

\footnotetext{
${ }^{16}$ Board of Relief and Humanitarian Affairs, 'Report on IDP camps in Duhok' (BRHA Duhok, 2015) <www.brhaduhok.org/wpcontent/uploads/Report\%20on\%20the\%20IDP\%20camps\%20in\%20Dohuk-June\%202015.pdf> accessed 8 May 2019

${ }^{17}$ Maha Sidky, Ariane Rummery, 'UNHCR steps up aid as Yazidis stream into Syria from Iraq’s Mount Sinjar' (UNHCR, 14 August 2014) <www.unhcr.org/uk/news/latest/2014/8/53ecb7a29/unhcr-steps-aid-yazidis-streamsyria-iraqs-mount-sinjar.html> accessed 10 May 2019

18 Tulin Daloglu, 'How will Turkey React to Stream of Kurdish Refugees?' (Al-Monitor, September 22 2014) $<$ www.al-monitor.com/pulse/originals/2014/09/turkey-syria-iraq-kobani-isis-kurds-pkk.html> accessed 8 May 2019

19 Editorial Staff, 'One doctor for 10,000 people in Iraq’s Yazidi Mount Sinjar' (Ekurd Daily, 2015) $<$ https://ekurd.net/one-doctor-for-10000-people-in-iraqs-yazidi-mount-sinjar-2015-01-13> accessed 10 May 2019

${ }^{20}$ REACH Initiative, 'REACH overview: Displacement from Sinjar, 3-14 August 2014' (2014) <www.reachinitiative.org/wpcontent/uploads/2014/08/REACH_IRQ_InternalDisplacement_Briefing_August2014_Sinjar.pdf> accessed 4 May 2019

${ }^{21}$ Convention on the Prevention and Punishment of Genocide (opened for signature 9 December 1948, entered into force 12 January 2002), 78 UNTS 277, Art 2
} 
The above acts were clearly committed during the ISIS attack on the Yazidis. In addition to the killings, members of the Yazidi community suffered serious bodily or mental harm due not only to the trauma executions and kidnappings themselves, but also as a result of the starvation, dehydration and exposure they suffered whilst surrounded on Mount Sinjar by ISIS forces. The execution of adults, the sexual slavery of women and the indoctrination of the children are all measures intended to prevent births within the group and thus compromise the sustainability of the Yazidi community. Similarly, the children who were kidnapped for sexual slavery or to fight were forcibly transferred from the Yazidi group to the ISIS group, which both destroyed their identities as Yazidi people and prevented them from continuing or rebuilding their Yazidi community. Furthermore, the siege of Mount Sinjar and the treatment of the kidnapped women and children constitute conditions of life deliberately imposed to bring about the physical destruction of the group, as these measures ensured that the entire Yazidi community was either killed or displaced.

By their very nature, the acts committed by ISIS amount to genocidal acts. However, the fact that the requisite act(s) are committed does not in itself amount to a genocide within the meaning of the Genocide Convention. The question, therefore, is in fact not whether these are genocidal acts, but rather whether these genocidal acts will amount to a genocide by reason of having been carried out against a protected group and with the required intent. Accordingly, the determination of the status of the Yazidi community and an exploration of ISIS' intent in carrying out these acts are central to identifying whether the Yazidi massacre constitutes a genocide.

\section{Identifying a 'Protected Group'}


A protected group within the meaning of the Rome Statute is one which is religious (consisting of individuals who "share the same religion, denomination or mode of worship" ${ }^{22}$ ), ethnic (“individuals who share a common language or culture"23), racial (conventionally meaning "the hereditary physical traits often identified with a geographical region, irrespective of linguistic, cultural, national or religious factors”24) or national (individuals "perceived to share a legal bond based on common citizenship, coupled with reciprocity of rights and duties”25 $)^{26}$.

Whilst this definition may be prima facie clear and definite, the identification of a group may present a challenge where the conflict arises within what an individual external to the situation would likely objectively consider one group. In these circumstances, the application of the convention definition becomes more uncertain. The determination of the composition of a group must therefore be made on a case-by-case basis ${ }^{27}$, and thus it is crucial to take a more subjective approach and consider the cultural context in which the conflict began - although some judgements support the view that a group must nonetheless have some objective existence $^{28}$. Particularly important here, is the notion that "collective identities ... are by their very nature social constructs”29, meaning that a group may also be identified by how the group distinguishes itself or how the group is perceived by others (including the perpetrator) ${ }^{30}$.

The Yazidis follow rules and customs governing their quotidian lives and view themselves very much external to those outside their community which may suggest they are a distinct

\footnotetext{
${ }^{22}$ Prosecutor v Akayesu (Judgment) ICTR-96-4-T (2 September 1998)

${ }^{23}$ Ibid.

${ }^{24}$ Ibid.

${ }^{25}$ Ibid.

${ }^{26}$ Rome Statute of the International Criminal Court 1998, Article 6

${ }^{27}$ Prosecutor v Brđanin (Judgement) IT-99-37-T (1 September 2004)

${ }^{28}$ Prosecutor v Rutaganda, (Judgement) ICTR-96-3-T (December 6 1999).

${ }^{29}$ Guglielmo Verdirame, “The Genocide Definition in the jurisprudence of the ad hoc tribunals”, (2000) 49 International and Comparative Law Quarterly 592.

${ }^{30}$ Prosecutor v. Kayishema and Ruzindana (Judgement) ICTR-95-1-T (May 21 1999)
} 
national group. However, this is also a somewhat more tenuous identification, as they also share common citizenship, a reciprocity of rights and duties with the rest of the Iraqi population, and certainly with neighboring communities. It is therefore quite unlikely that the Yazidis could be properly considered a separate national group.

The Yazidi people believe that they were created first before any other race of people, as they are descended from Adam only, whilst the rest of humanity was later created and descended from both Adam and $\mathrm{Eve}^{31}$. Therefore, insofar as a group may be defined by its self-perception and self-identification, it may be argued that the Yazidi people are indeed a distinct racial group. However, it should be noted that this is perhaps a more tenuous distinction in comparison to identifying the Yazidis as a religious or ethnic group, as it may be argued that, geographically (notwithstanding their language, culture, religion or nationality as suggested in Akayesu), the Yazidis belong to the wider Kurdish racial group and therefore are not a distinct racial group.

Moreover, the fact that ISIS appear to have viewed and targeted the Yazidis as a distinct group on the grounds of their cultural and religious identity, as opposed to their racial identity, would also suggest that it is unlikely that the Yazidis could be properly considered a distinct racial group within the meaning of the Genocide Convention. This is particularly unlikely in light of the fact that the perception of the perpetrator and his subjective belief that the individuals in question are part of a distinct group is a more persuasive and arguably appropriate means by

\footnotetext{
${ }^{31}$ Who, What Why, 'Who are the Yazidis?' (BBC, 8 August 2014) < http://www.yeziditruth.org > accessed 9 May 2019 
which a protected group should be identified ${ }^{32}$ - indeed, the perpetrator's intent is inevitably “a decisive element in the crime of genocide” 33 .

One may also consider that the Yazidis in fact speak the same Kurdish language as other Kurds, and many also speak Arabic due to their proximity to Arab neighbourhoods ${ }^{34}$, and therefore the Yazidis are arguably not a distinct ethnic group from other Kurds or Arabs. However, the definition of 'ethnic' encompasses “language or culture”, and whilst they may share a common language, they evidently do not share broader Kurdish culture. For example, contact with outsiders is discouraged and so Yazidis often seek to avoid formal education and military service $^{35}$. The Yazidi people also follow specific rules, such as the prohibition of blue clothing, certain foods and the pronunciation of the word 'Shaytân' (Satan). It would therefore be appropriate to consider the Yazidi people as a distinct ethnic group.

Perhaps most saliently, the Yazidis are also a distinct religious minority, as they hold particular and unique beliefs and customs which combine elements of Islam, Zoroastrianism, Christianity and Judaism spanning thousands of years ${ }^{36}$ and differ from neighbouring groups. Moreover, Yazidis do not allow conversions into or out of the Yazidi community further demonstrating that the Yazidi people view themselves as a distinct group which is not only religious, but ethnic as well. ISIS on their part have branded the Yazidi people as “devil worshippers” ${ }^{37}$ and

\footnotetext{
32 Prosecutor v Jelisić (Judgement) IT-95-10-T (14 December 1999)

33 William A. Schabas, 'Was Genocide Committed in Bosnia and Herzegovina? First Judgments of the International Criminal Tribunal for the Former Yugoslavia’ (2001) 25 Fordham International Law Journal 23

${ }^{34}$ Dave van Zoonen, Khogir Wirya, 'Yazidis: Perceptions of Reconciliation and Conflict' (2017) Middle East Research Institute <www.usip.org/sites/default/files/Yazidis-Perceptions-of-Reconciliation-and-ConflictReport.pdf $>$ accessed 7 May 2019

35 The Editors of Encyclopaedia Britannica 'Encyclopaedia Britannica: 'Yazīdī' (Encyclopaedia Britanica inc. 2018) <www.britannica.com/topic/Yazidi > accessed 4 May 2019

${ }^{36}$ OHCHR, 'Report of the Independent International Commission of Inquiry on the Syrian Arab Republic' (15 June 2016) A/HRC/32/CRP.2

${ }^{37}$ Simon-Skjodt Center for the Prevention of Genocide, ““Our Generation is gone.” The Islamic State’s targeting of Iraqi minorities in Ninewa' (2015) < https://www.ushmm.org/m/pdfs/Iraq-Bearing-Witness-Report111215.pdf> accessed 5 May 2019
} 
“infidels”38, demonstrating that as perpetrators, they also perceive the Yazidis as a distinct group.

However, although the subjective approach is an important contextual consideration, it cannot always be properly regarded as the only consideration in the identification of a protected group. Arguably, the objective existence of the group must also be determined to ensure that the law does not "permit the crime to be defined by the offender alone" 39 .

This being said, a protected group will most often be apparent in the specific context of each case $^{40}$. Indeed, in the case of the Yazidi massacre, it appears evident that the Yazidis constitute a religious and ethnic group, both objectively and from their own, and crucially, the perpetrator's own, subjective perspective. As such, the Yazidis clearly fall within the scope of ‘protected group’ under both the statutory and case law definitions.

\section{$\underline{\text { A Group 'in Whole or in Part' }}$}

International case law has made clear that a 'part' of the group amounts to a "substantial part”41 or a “considerable number of individuals”42 - though not necessarily a “very important part”43 of the group. It is also suggested that 'in part' indicates "a reasonably significant number, relative to the total of the group as a whole, or else a significant section of a group such as its

\footnotetext{
38 OHCHR, 'Report of the Independent International Commission of Inquiry on the Syrian Arab Republic' (15 June 2016) A/HRC/32/CRP.2

39 William A. Schabas, 'Was Genocide Committed in Bosnia and Herzegovina? First Judgments of the International Criminal Tribunal for the Former Yugoslavia’ (2001) 25 Fordham International Law Journal 23

${ }^{40}$ Max van der Stoel, 'Prevention of Minority Conflicts', in Louis B. Sohn (ed) The CSCE and the Turbulent New Europe (Friedrich-Naumann-Stiftung 1993)

${ }^{41}$ Prosecutor v Semanza (Judgement) ICTR-97-20-T (15 May 2003)

42 Prosecutor v Kayishema and Ruzindana (Judgement) ICTR-95-1-T (21 May 1999)

43 Prosecutor v Jelisić (Judgement) IT-95-10-T (14 December 1999)
} 
leadership" ${ }^{44}$. The Yazidi population is estimated at less than 1.5 million $^{45}$, with communities primarily located across Iraq, Syria, Turkey, and Armenia. Therefore, whilst the attack on the Yazidis of the Sinjar area evidently targets only part of the population, crucially, it targets the largest community of that population - and moreover, 400,000 out of 1.5 million Yazidis (nearly one third) clearly amounts to a 'significant part' of the group relative to the total.

Furthermore, it may be pertinent to consider the United States’ implementation of the Genocide Convention in its domestic legislation, in which 'substantial part' is defined as "a part of a group of such numerical significance that the destruction or loss of that part would cause the destruction of the group as a viable entity within the nation of which such group is a part." ${ }^{46}$ By attacking the Sinjar community specifically - the largest and culturally most significant Yazidi community - whether by means of killing, preventing the continuation of births, religious practices or the rebuilding of the community, it was inevitable that there would be lasting repercussions on not only this specific community, but also the Yazidi people as a whole.

\section{Genocidal Intent - 'Dolus Specialis'}

Aside from consideration of the acts and the protected parties themselves, the presence of genocidal intent is the crux of identifying a genocide, as it is this element of 'surplus intent' 47

\footnotetext{
${ }^{44}$ Ben Whitaker, 'Revised and Updated Report on the Question of the Prevention and Punishment of the Crime of Genocide’, UN Doc. E/CN.4/Sub.2/1985/6

${ }^{45}$ Valeria Cetorelli, Isaac Sasson, Nazar Shabila, Gilbert Burnham 'Mortality and kidnapping estimates for the Yazidi population in the area of Mount Sinjar, Iraq, in August 2014: A retrospective household survey’ (2017) PLOS Medicine

${ }^{46}$ Genocide Convention Implementation Act 1987, s.1093 (8) (US)

${ }^{47}$ Prosecutor v Stakić (Judgement) IT-97-24 (31 July 2003)
} 
that decisively sets apart the crime of genocide from other lesser crimes ${ }^{48}$, such as crimes against humanity or war crimes. Genocidal intent is a 'dolus specialis' (special intent) which imposes a requirement that the perpetrator specifically intends to produce the act charged. It is two-fold ${ }^{49}$ in that Genocidal intent requires both the criminal intent to commit the underlying crime (for example, causing grievous bodily harm) and the specific intent 'to destroy in whole or in part' the targeted group ${ }^{50}$. Importantly, the genocide must target the group 'as such' meaning as a "separate and distinct entity" 51, as opposed to only one or several individuals for a particular reason. The victims must have been targeted because of the fact that they belonged to a particular group, and as a means of destroying the group to which they belong ${ }^{52}$.

In the absence of direct evidence of genocidal intent, it may be inferred from a number of facts and circumstances, for instance the general context, the deliberate and systematic targeting of members of a group whilst sparing non-members, the scale of atrocities committed ${ }^{53}$, the physical targeting of the group or their property, the number or proportion of the group affected and the derogatory language used towards them ${ }^{54}$. Furthermore, it is for the court to determine the appropriate requirement to be met for establishing a mental element regarding knowledge of the circumstances on a case-by-case basis ${ }^{55}$ and, whilst the 'existence of a plan or policy is not a legal ingredient of the crime ${ }^{56}$, it may go to evidence genocidal intent.

\footnotetext{
48 International Law Commission, 'Draft Code of Crimes Against the Peace and Security of Mankind with commentaries', 1996

${ }^{49}$ International Commission of Inquiry on Darfur, 'Report of the International Commission of Inquiry on Darfur to the United Nations Secretary-General’ (25 January 2005)

${ }^{50}$ Application of the Convention on the Prevention and Punishment of the Crime of Genocide (Croatia v. Serbia)

${ }^{51}$ International Law Commission, 'Draft Code of Crimes Against the Peace and Security of Mankind with commentaries', 1996

52 Prosecutor v. Rutaganda (Judgment) ICTR-96-3 (6 December 1999)

53 Prosecutor v Akayesu (Judgment)ICTR-96-4-T, T Ch I (2 September 1998)

${ }^{54}$ Kayishema and Ruzindana (Judgement) ICTR-95-1-T (21 May 1999)

${ }^{55}$ Elements of Crimes, Article 6

${ }^{56}$ Prosecutor v Jelisić (Appeal Judgement) IT-95-10 (5 July 2001)
} 
Most indicative of ISIS' genocidal intent is the specific type of attacks carried out and the way in which they were conducted. The attacks were tailored to the religious and cultural customs of the Yazidi people so as to efficiently target and undermine them and cause the community to collapse. The killing of older men and women ensured that families could rarely be rebuilt and that military aged men could not aid in the defence of the community. It also meant that many women who survived and were able to re-join their families - particularly women with limited education (as was the case for many) or those from rural areas - struggled to survive, as they lacked personal and financial independence and had relied heavily on their husbands for communication beyond their own families. ${ }^{57}$ The abduction and indoctrination of the children - whether as slaves or as fighters - worked to destroy the culture and religion that the younger generation would have grown up around and continued, as well as preventing them from trying to return to their community and rebuild it.

The sexual slavery of the young women was also designed to be destructive in a unique way in this cultural context, as until recently, children born as a result of ISIS rapes would not be allowed into the Yazidi faith/culture due to the fact that Yazidism requires a child to have two Yazidi parents ${ }^{58}$ and Iraqi law dictates that children should be registered under the religion of their fathers. Therefore, women were required to give up their child before being allowed to re-join the community - it only as of 24 April 2019 that the Yazidi Supreme Spiritual Council have decreed that they will accept both the ISIS rape survivors and their children back into the community ${ }^{59}$.

\footnotetext{
${ }^{57}$ OHCHR, 'Report of the Independent International Commission of Inquiry on the Syrian Arab Republic' (15 June 2016) A/HRC/32/CRP.2

${ }^{58}$ OHCHR, 'Report of the Independent International Commission of Inquiry on the Syrian Arab Republic' (15 June 2016) A/HRC/32/CRP.2

${ }^{59}$ Martin Chulov, 'Yazidi leaders to allow Isis rape survivors to return with children' The Guardian (27 April 2019)
} 
The specific choice to target the Sinjar region further goes to evidence the intent to destroy the Yazidi community. This is not only the largest Yazidi community, but importantly the Nineveh-Dohuk and Sinjar region is home to their shrines, holy places and ancestral lands ${ }^{60}$ which are central to the Yazidi cultural and religious identity, particularly the main temple in Lalesh as they believe this is where creation began ${ }^{61}$. Arguably, the choice to attack the most prominent Yazidi community, one that is "emblematic of the overall group" 62 is a deliberate choice not only in terms of the significant number of potential victims, but also in terms of threatening, weakening or terrorising the other, smaller Yazidi communities and the Yazidi faith and ethnic group as a whole.

Moreover, these attacks were carried out on civilians of all ages, genders and professions ${ }^{63}$ (as opposed to military forces only). Although civilians "undoubtedly are capable of bearing arms, they do not constitute the same kind of military threat as professional soldiers" ${ }^{64}$, and therefore the indiscriminate nature of the attack demonstrates a disregard the rules of war and strongly suggests that this was not solely a military attack but a distinct attempt to target and destroy the group itself.

However, there is scope to argue that the attack on the Yazidis was 'ethnic cleansing' as opposed to genocide. Whilst both horrific crimes, genocide requires the intent to destroy,

\footnotetext{
60 Practice Lab Report, 'Executive Summary' (Vanderbilt Law School) $<$ https://law.vanderbilt.edu/academics/academic-programs/international-legalstudies/Yazidi_Genocide_Opinion_KRG_4.15.pdf> accessed 9 May 2019

${ }^{61}$ Dave van Zoonen, Khogir Wirya,'Yazidis: Perceptions of Reconciliation and Conflict' (2017) Middle East Research Institute <www.usip.org/sites/default/files/Yazidis-Perceptions-of-Reconciliation-and-ConflictReport.pdf $>$ accessed 8 May 2019

62 Prosecutor v. Popovic (Judgement) IT-05-88-T (10 June 2010)

63 Valeria Cetorelli, Isaac Sasson, Nazar Shabila, Gilbert Burnham'Mortality and kidnapping estimates for the Yazidi population in the area of Mount Sinjar, Iraq, in August 2014: A retrospective household survey’ (2017) PLOS Medicine

${ }^{64}$ Prosecutor v Krstić (Judgment) ICTR-98-33-A (19 April 2004)
} 
whereas ethnic cleansing instead refers to the intent to displace a group, "a purposeful policy designed by one ethnic or religious group to remove by violent and terror-inspiring means the civilian population of another ethnic or religious group from certain geographic areas”. ${ }^{65}$ ISIS very clearly regarded the attack as a means of 'purifying', and has specifically targeted the Sinjar area. Furthermore, the Yazidis were in fact one of several persecuted non-Islamic minorities in the area ${ }^{66}$, and whilst this particular attack specifically targeted the Yazidi people, one may argue that it was not carried out with the genocidal intent to destroy the Yazidi group but rather one attack in a series of attacks intended to displace any group that was not ISIS. Therefore, the ISIS attack on the Yazidis is arguably one aimed at ethnic cleansing, and as such may amount to crimes against humanity or war crimes, but not genocide ${ }^{67}$.

\section{Genocide versus Crimes Against Humanity}

It has been argued that 'crimes against humanity' would be more appropriate to define crimes such as those carried out during the Yazidi massacre, with some even going on to posit that the concept of 'genocide' does little, if anything, to add to international criminal law except create a "discrimination between protected groups that has no grounding in legal theory" ${ }^{6}$, and therefore there should be "sole reliance on crimes against humanity" ${ }^{69}$ which already provides for the underlying acts of genocide.

\footnotetext{
65 United Nations Security Council, 'Report of the Commission of Experts on the evidence of grave breaches of the Geneva Conventions and other violations of international humanitarian law committed in the territory of the former Yugoslavia’ (27 May 1994) S/1994/674

${ }^{66}$ Simon-Skjodt Center for the Prevention of Genocide, ““Our Generation is gone.” The Islamic State’s targeting of Iraqi minorities in Ninewa' (2015) < https://www.ushmm.org/m/pdfs/Iraq-Bearing-Witness-Report111215.pdf> accessed 5 May 2019

${ }^{67}$ Application of the Convention on the Prevention and Punishment of the Crime of Genocide (Croatia v. Serbia)

${ }^{68}$ Dov Jacobs, 'Moving Past the Genocide Debate: Mass Atrocities and the International Community', Theory vs. Policy? Connecting Scholars and Practitioners, (ISA Annual Convention 2010, New Orleans 69 ibid
} 
However, the majority of jurisdictions "recognize degrees of the crime based on differences in the mental element alone» ${ }^{70}$ even where the act(s) committed are identical ${ }^{71}$. This could equally apply to the crime of genocide, which, despite the elements of actus reus it shares with crimes against humanity ${ }^{72}$, is differentiated and aggravated by the genocidal intent element ${ }^{73}$ which is omitted from crimes against humanity ${ }^{74}$. Therefore, the term 'genocide', should not be conflated with 'crimes against humanity ${ }^{75}$, despite the potential definitional overlap ${ }^{76}$. In the instance of the Yazidi massacre, ISIS’ genocidal intent is readily inferred, and thus the crimes take on "a further degree of seriousness"77, and surpass the threshold required for crimes against humanity. To label them as such would therefore be inaccurate and inappropriate, as it would not properly acknowledge the exact nature of the crimes that took place and undermine the true severity of this case.

\section{The Wider Implications of a Finding of 'Genocide’}

The label 'genocide' is important not only in terms of its accuracy in describing the crimes but also because of the political significance and legal implications attached to the term. The importance of the correct terminology becomes particularly apparent when consideration is given to the correlation between the type of crime and the measures required.

\footnotetext{
${ }^{70}$ William A. Schabas, Genocide in International Law: The Crime of Crimes (Cambridge University Press, 2009) 241

71 ibid

72 Rome Statute of the International Criminal Court 1998, Article 7

${ }^{73}$ Akhavan P, Reducing Genocide to Law: Definition, Meaning, and the Ultimate Crime (Cambridge University Press, 2012)

${ }^{74}$ Prosecutor v Akayesu (Judgment) ICTR-96-4-A (1 June 2001)

75 Schabas W A., Genocide in International Law: The Crime of Crimes (Cambridge University Press, 2009$) 15$

${ }^{76}$ Dov Jacobs, 'Moving Past the Genocide Debate: Mass Atrocities and the International Community', Theory vs. Policy? Connecting Scholars and Practitioners, (ISA Annual Convention 2010, New Orleans

${ }^{77}$ Wibke K. Timmermann, Book Review (2013) 72 Journal of International Criminal Justice 485
} 
Genocide is widely regarded one of the gravest crimes, and as such, there are implications for the kind of response and attention it receives. For example, the term is often perceived to have the "ability to motivate public opinion and mobilize international consensus"78. In theory, the label 'genocide' also has the "legal power to bind states to take action to halt genocide"79. It is true, however, that in practice, it may at times be counterproductive and lead to states avoiding the use this label to evade any obligation they may have to intervene ${ }^{80}$. In fact, even where the conclusion has been reached that a genocide has occurred, action has not always been forthcoming - the United States' inaction during the conflict in Darfur being an example of this ${ }^{81}$.

This being said, despite the shortcomings to date in addressing these issues, the use of the term genocide nonetheless carries "the heaviest stigma in the popular and in the diplomatic world" 82 , and is potentially very powerful in determining "how we react to and prevent the gravest of international crimes” ${ }^{83}$. Therefore, though the primary importance of defining the Yazidi massacre a 'genocide' lies it its legal distinction from other crimes, it is evident that the ramifications of such a finding would extend beyond the legal system.

\section{Conclusion}

\footnotetext{
${ }^{78}$ Mark Kersten, 'You Say Genocide, I Say Genocide: Some Thoughts on the Genocide Debate', (Justice in Conflict, 5 June 2011) <https://justiceinconflict.org/2011/06/05/you-say-genocide-i-say-genocide-somethoughts-on-the-genocide-debate-2/> accessed 17 November 2019

79 ibid

80 ibid

81 Secretary Colin L. Powell, 'The Crisis in Darfur' (US Department of State Archive, 9 September 2004) <https://2001-2009.state.gov/secretary/former/powell/remarks/36042.htm> accessed 17 November 2019

${ }^{82}$ Patricia M. Wald, 'Genocide and Crimes against Humanity' (2007) 6 Washington University Global Studies Law Review 621

${ }^{83}$ Mark Kersten, 'You Say Genocide, I Say Genocide: Some Thoughts on the Genocide Debate', (Justice in Conflict, 5 June 2011) <https://justiceinconflict.org/2011/06/05/you-say-genocide-i-say-genocide-somethoughts-on-the-genocide-debate-2/> accessed 17 November 2019
} 
In conclusion, the acts committed by ISIS against the Yazidis satisfy the statutory definition of genocide as set out by the Genocide Convention of 1948: genocidal acts were committed, the Yazidis constitute a protected group, and ISIS appear to have the requisite genocidal intent to destroy, at least in part, the Yazidi community.

Both killing and causing serious bodily or mental harm as genocidal act require proof of a result ${ }^{84}$. The sheer scale of the atrocities which targeted one third of the global Yazidi population evidences not only the commission of the acts themselves but the destructive intent of the perpetrators ${ }^{85}$. The mental and bodily harm suffered (though not necessarily permanent and irreversible ${ }^{86}$ ) goes “beyond temporary unhappiness, embarrassment or humiliation”, and has resulted “in a grave and long-term disadvantage to a person's ability to lead a normal and constructive life" ${ }^{87}$ as required by case law.

The conditions of life imposed on those subjected to the siege of Mount Sinjar were clearly intended to ultimately bring about the physical destruction of the Yazidis due to the lack of supplies and medical care ${ }^{88}$. With regards to the conditions of life imposed on those kidnapped for slavery and indoctrination, it may be argued that they were calculated to dissolve (but not destroy) the group which would constitute a crime against humanity, but not a genocidal act ${ }^{89}$. However, the conditions of life were nonetheless measures which prevented births within the group and forcibly transferred children. Ultimately, whilst a plan or policy is not required to establish genocidal intent ${ }^{90}$, the range of acts that ISIS committed against the Yazidis during the attack and the way in which they were carried out demonstrates a "context of a manifest

\footnotetext{
${ }^{84}$ Prosecutor v Brđanin (Judgement) IT-99-36-T (1 September 2004)

${ }^{85}$ Prosecutor $v$ Karadžić (Judgement) MICT-13-55 (24 March 2016)

${ }^{86}$ Prosecutor v Tolimir (Judgement) IT-05-88/2-T (12 December 2012)

${ }^{87}$ Prosecutor v Krstić (Judgment) ICTR-98-33-A (19 April 2004)

${ }^{88}$ Prosecutor $v$ Musema (Judgment) ICTR-96-13-A (27 January 2000)

${ }^{89}$ Prosecutor v Brđanin (Judgement) IT-99-36-T (1 September 2004)

${ }^{90}$ Prosecutor v Jelisić (Judgement) IT-95-10-A (5 July 2001)
} 
pattern of conduct aimed at the destruction"91 of the Yazidi group specifically. Therefore, the ISIS attack on the Yazidis does indeed constitute a genocide and it is important that it be recognised as such. Despite this, and despite the fact that the International Criminal Court (ICC) has jurisdiction over crimes of genocide ${ }^{92}$ and that arguably, universal jurisdiction may also apply (considering the severity of the crime and the involvement of ISIS which is of global concern), individual perpetrators - or indeed co-perpetrators - have yet to be prosecuted. Meanwhile, several thousand Yazidis are still in ISIS captivity and thus the genocide is ongoing ${ }^{93}$.

${ }^{91}$ OHCHR, 'Report of the Office of the United Nations High Commissioner for Human Rights on the human rights situation in Iraq in the light of abuses committed by the so-called Islamic State in Iraq and the Levant and associated groups (ISIS)' (13 March 2015) A/HRC/28/18

${ }^{92}$ Rome Statute of the International Criminal Court 1998, Article 5

${ }^{93}$ OHCHR, 'Report of the Independent International Commission of Inquiry on the Syrian Arab Republic' (15 June 2016) A/HRC/32/CRP.2 


\section{Bibliography}

\section{$\underline{\text { Primary Sources }}$}

- Convention on the Prevention and Punishment of Genocide (opened for signature 9 December 1948, entered into force 12 January 2002), 78 UNTS 277

- Elements of Crimes 2010

- $\quad$ Rome Statute of the International Criminal Court 1998

- Genocide Convention Implementation Act 1987 (US)

- Application of the Convention on the Prevention and Punishment of the Crime of Genocide (Croatia v. Serbia)

- Prosecutor v Akayesu (Judgment) ICTR-96-4-A (1 June 2001)

- Prosecutor v Akayesu (Judgment) ICTR-96-4-T (2 September 1998)

- Prosecutor v Brđanin (Judgement) IT-99-37-T (1 September 2004)

- Prosecutor v Jelisić (Judgement) IT-95-10-T (14 December 1999)

- Prosecutor v Karadžić (Judgement) MICT-13-55 (24 March 2016)

- Prosecutor v Kayishema and Ruzindana (Judgement) ICTR-95-1-T (21 May 1999)

- Prosecutor v Krstić (Judgment) ICTR-98-33-A (19 April 2004)

- Prosecutor v Musema (Judgment) ICTR-96-13-A (27 January 2000)

- Prosecutor v Rutaganda, (Judgement) ICTR-96-3-T (December 6 1999)

- Prosecutor v Semanza (Judgement) ICTR-97-20-T (15 May 2003)

- Prosecutor v Stakić (Judgement) IT-97-24 (31 July 2003)

- Prosecutor v Tolimir (Judgement) IT-05-88/2-T (12 December 2012)

- Prosecutor v. Popovic (Judgement) IT-05-88-T (10 June 2010)

\section{Secondary Sources}

- Akhavan P, Reducing Genocide to Law: Definition, Meaning, and the Ultimate Crime (Cambridge University Press, 2012)

- Amnesty International ‘Ethnic cleansing on a historic scale: Islamic State’s systematic targeting of minorities in Northern Iraq' (2014)

<www.es.amnesty.org/uploads/media/Iraq_ethnic_cleansing_final_formatted.pdf > accessed 4 May 2019

- Board of Relief and Humanitarian Affairs, 'Report on IDP camps in Duhok' (BRHA Duhok, 2015) <www.brhaduhok.org/wpcontent/uploads/Report\%20on\%20the\%20IDP\%20camps\%20in\%20Do huk-June\%202015.pdf> accessed 8 May 2019

- Cetorelli V, Sasson I, Shabila N, Burnham G, 'Mortality and kidnapping estimates for the Yazidi population in the area of Mount Sinjar, Iraq, in August 2014: A 
retrospective household survey' (2017) PLOS Medicine

<https://doi.org/10.1371/journal.pmed.1002297> accessed 4 May 2019

- Chulov M, 'Yazidi leaders to allow ISIS rape survivors to return with children' The Guardian (27 April 2019)

- Daloglu T, 'How will Turkey React to Stream of Kurdish Refugees?' (Al-Monitor, September 22 2014) <www.al-monitor.com/pulse/originals/2014/09/turkey-syria-iraqkobani-isis-kurds-pkk.html> accessed 8 May 2019

- Editorial Staff, 'One doctor for 10,000 people in Iraq’s Yazidi Mount Sinjar' (Ekurd Daily, 2015) <https://ekurd.net/one-doctor-for-10000-people-in-iraqs-yazidi-mountsinjar-2015-01-13> accessed 10 May 2019

- International Commission of Inquiry on Darfur, 'Report of the International Commission of Inquiry on Darfur to the United Nations Secretary-General’ (25 January 2005)

- International Law Commission, 'Draft Code of Crimes Against the Peace and Security of Mankind with commentaries’, 1996

- International Law Commission, 'Draft Code of Crimes Against the Peace and Security of Mankind with commentaries’, 1996

- Jacobs D, 'Moving Past the Genocide Debate: Mass Atrocities and the International Community', Theory vs. Policy? Connecting Scholars and Practitioners, (ISA Annual Convention 2010, New Orleans

- Jewish World Watch, 'Iraq (The Yazidis)' (Jewish World Watch, 2019) <www.jww.org/conflict-areas/iraq-yazidis/> accessed 4 May 2019

- Kersten M, 'You Say Genocide, I Say Genocide: Some Thoughts on the Genocide Debate', (Justice in Conflict, 5 June 2011) $<$ https://justiceinconflict.org/2011/06/05/you-say-genocide-i-say-genocide-somethoughts-on-the-genocide-debate-2/> accessed 17 November 2019

- OHCHR, 'Report of the Independent International Commission of Inquiry on the Syrian Arab Republic’ (15 June 2016) A/HRC/32/CRP.2

- OHCHR, 'Report of the Office of the United Nations High Commissioner for Human Rights on the human rights situation in Iraq in the light of abuses committed by the so-called Islamic State in Iraq and the Levant and associated groups (ISIS)' (13 March 2015) A/HRC/28/18

- Practice Lab Report, 'Executive Summary’ (Vanderbilt Law School) $<$ https://law.vanderbilt.edu/academics/academic-programs/international-legalstudies/Yazidi_Genocide_Opinion_KRG_4.15.pdf> accessed 9 May 2019

- $\quad$ REACH Initiative, 'REACH overview: Displacement from Sinjar, 3-14 August 2014' (2014) < www.reach-initiative.org/wpcontent/uploads/2014/08/REACH_IRQ_InternalDisplacement_Briefing_August2014 _Sinjar.pdf $>$ accessed 4 May 2019

- Schabas W A., 'Was Genocide Committed in Bosnia and Herzegovina? First Judgments of the International Criminal Tribunal for the Former Yugoslavia' (2001) 25 Fordham International Law Journal 23 
- Schabas W A., Genocide in International Law: The Crime of Crimes (Cambridge University Press, 2009)

- Secretary Colin L. Powell, 'The Crisis in Darfur' (US Department of State Archive, 9 September 2004) <https://2001-

2009.state.gov/secretary/former/powell/remarks/36042.htm> accessed 17 November 2019

- Sidky M, Rummery A, 'UNHCR steps up aid as Yazidis stream into Syria from Iraq’s Mount Sinjar' (UNHCR, 14 August 2014)

$<$ www.unhcr.org/uk/news/latest/2014/8/53ecb7a29/unhcr-steps-aid-yazidis-streamsyria-iraqs-mount-sinjar.html> accessed 10 May 2019

- Simon-Skjodt Center for the Prevention of Genocide, “"Our Generation is gone.” The Islamic State's targeting of Iraqi minorities in Ninewa' (2015)

$<$ https://www.ushmm.org/m/pdfs/Iraq-Bearing-Witness-Report-111215.pdf > accessed 5 May 2019

- The Editors of Encyclopaedia Britannica 'Encyclopaedia Britannica: 'Yazīdī' (Encyclopaedia Britanica inc. 2018) <www.britannica.com/topic/Yazidi > accessed 4 May 2019

- Timmermann W K., Book Review (2013) 72 Journal of International Criminal Justice 485

- United Nations Security Council, 'Report of the Commission of Experts on the evidence of grave breaches of the Geneva Conventions and other violations of international humanitarian law committed in the territory of the former Yugoslavia' (27 May 1994) S/1994/674

- United Nations, 'Report of the International Commission of Inquiry on Darfur to the United Nations Secretary-General' (25 January 2005)

- van der Stoel M, 'Prevention of Minority Conflicts', in Louis B. Sohn (ed) The CSCE and the Turbulent New Europe (Friedrich-Naumann-Stiftung 1993)

- $\quad$ van Zoonen D, Wirya K, 'Yazidis: Perceptions of Reconciliation and Conflict' (2017) Middle East Research Institute <www.usip.org/sites/default/files/Yazidis-Perceptionsof-Reconciliation-and-Conflict-Report.pdf> accessed 4 May 2019

- Verdirame G, “The Genocide Definition in the jurisprudence of the ad hoc tribunals", (2000) 49 International and Comparative Law Quarterly 592

- Wald P M., ‘Genocide and Crimes against Humanity’ (2007) 6 Washington University Global Studies Law Review 621

- Whitaker B, 'Revised and Updated Report on the Question of the Prevention and Punishment of the Crime of Genocide', UN Doc. E/CN.4/Sub.2/1985/6

- Who, What Why, 'Who are the Yazidis?' (BBC, 8 August 2014) $<$ http://www.yeziditruth.org > accessed 9 May 2019

- Yazda and the Free Yezidi Foundation, 'ISIL: Nationals of ICC states parties committing genocide and other crimes against the Yazidis' (Free Yezidi Foundation, 2015) <www.freeyezidi.org/wp-content/uploads/Corr-RED-ISIL-commitinggenocide-ag-the-Yazidis.pdf> accessed 5 May 2019 